\title{
University teaching versus the M00C: Reports from the field, current trends, and future directions
}

Thierry Karsenti

Université de Montréal

Christian Depover Université de Mons

Vassilis Komis Université de Patras

Gabriel Dumouchel Université de Montréal
Despite the fact that some researchers consider the MOOC the most important experiment to date in university teaching (Weissmann, 2012), and despite the fact that The New York Times named 2012 "The Year of the MOOC" (Pappano, 2012), we now realize that this new form of university teaching poses a number of challenges for designers, educators, and students alike. We also note a growing trend: the success of a MOOC is not necessarily measured in terms of the number of students who complete the course, but instead the number of students who enroll in it. These steep drop-out rates have been called a "funnel of participation" (Clow, 2013).

This special thematic issue aims to add to the literature by presenting diverse perspectives on this contemporary problem. Featured articles will include reports of experiences in France (Bar-Hen, Javaux, \& Villa-Vialaneix), an examination of passive and active retention rates in Belgium (Schiffino, Cogels, Baudewyns, Hamonic, Legrand, \& Reuchamps), an enquiry into MOOC participation in France (Khaneboubi \& Baron), attention channeling strat- egies in Switzerland (Sharma, Caballero, Verma, Jermann, \& Dillenbourg), the design of a user interface for MOOC participants in Nebraska, USA $\mathrm{Vu})$, regional differences among Francophone students enrolled in a MOOC in Canada (Roy, Poellhuber, \& Bouchoucha), French educators perceptions of web-based teaching (Trestini \& Rossini), ways to update MOOCs in France (Pélissier \& Duthoit), a critical analysis of media discourses on MOOCs (Collin \& Saffari), and strategies to foster learner engagement in a MOOC (Karsenti). This special issue also presents two very useful infographics that could help better understand MOOCs: MOOC, faits et chiffres and MOOC: Facts and Figures.

This collection of articles will cast more light on the MOOC phenomenon in today's university systems. The hope is to open the way to a deeper understanding of the issues and to help overcome barriers to engagement and success in this growing international teaching mode. 


\section{Références}

Clow, Doug (2013). MOOCs and the funnel of participation. In: Third Conference on Learning Analytics and Knowledge (LAK 2013), 8-12 April 2013, Leuven, Belgium, pp. 185-189.

Pappano, L. (2012, November 2). The Year of the MOOC. New York Times, ED26. Retrieved from: http://nytimes.com

Weissmann, J. (2012, 18 July). The single most important experiment in higher education. Retrieved from: http://theatlantic.com 